\title{
Genetic structure among sorghum landraces as revealed by morphological variation and microsatellite markers in three agroclimatic regions of Burkina Faso
}

\author{
Clarisse Barro-Kondombo • Fabrice Sagnard • Jacques Chantereau • \\ Monique Deu • Kirsten vom Brocke • Patrick Durand • Eric Gozé • \\ Jean Didier Zongo
}

Received: 20 October 2008/ Accepted: 19 January 2010/Published online: 24 February 2010

(C) Springer-Verlag 2010

\begin{abstract}
Diversity among 124 sorghum landraces from 10 villages surveyed in 3 regions of Burkina Faso covering different agroecological zones was assessed by 28 agromorphological traits and 29 microsatellite markers. $94.4 \%$ of the landraces collected belonged to the botanical race guinea (consisting of $96.6 \%$ guinea gambicum and $3.4 \%$
\end{abstract}

Communicated by A. Charcosset.

C. Barro-Kondombo

INERA, CRREA du Centre, BP 10 Koudougou, Burkina Faso

F. Sagnard · M. Deu

CIRAD, UMR Développement et Amélioration

des Plantes, Montpellier 34398, France

F. Sagnard

International Center of Research for the Semi-Arid Tropics

(ICRISAT), P.O. Box 39063, Nairobi, Kenya

J. Chantereau $(\bowtie) \cdot$ K. vom Brocke

CIRAD, UPR Adaptation Agroécologique

et Innovation Variétale, Montpellier 34398, France

e-mail: jacques.chantereau@cirad.fr

K. vom Brocke

International Center of Research for the Semi-Arid Tropics

(ICRISAT), BP 320 Bamako, Mali

P. Durand

IRD, UMR CNRS-IRD2724-Génétique et Evolution des maladies infectieuses, 911 Avenue Agropolis, BP 64501, 34394 Montpellier Cedex 5, France

E. Gozé

CIRAD, UPR Systèmes de Culture Annuels, Montpellier 34398, France

J. D. Zongo

Université de Ouagadougou, UFR Sciences de la Vie et de la Terre, 03, BP 7021 Ouagadogou 03, Burkina Faso guinea margaritiferum), $74.2 \%$ had white kernels, $13.7 \%$ had orange and $12.1 \%$ had red kernels. Compared to the "village nested within zone" factor, the "variety nested within village within zone" factor predominately contributed to the diversity pattern for all nine statistically analysed quantitative traits. The multivariate analyses performed on ten morphological traits identified five landrace groups, and of these, the red kernel sorghum types appeared the most homogenous. 2 to 17 alleles were detected per locus with a mean 4.9 alleles per locus and a gene diversity $(\mathrm{He})$ of 0.37 . Landraces from the subSahelian zone had the highest gene diversity $(\mathrm{He}=0.38)$. Cluster analysis revealed that the diversity was weakly stratified and could not be explained by any biophysical criteria. One homogenous guinea margaritiferum group was distinguished from other guinea landraces. The red kernel type appeared to be genetically distinct from all other guinea landraces. The kernel colour was the principal structuring factor. This is an example of a homogeneous group of varieties selected for a specific use (for local beer preparation), mainly grown around the households in compound fields, and presenting particular agromorphological and genetic traits. This is the most original feature of sorghum diversity in Burkina Faso and should be the focus of special conservation efforts.

\section{Introduction}

Sorghum (Sorghum bicolor [L.] Moench) has been cultivated for human consumption since ancient times. Domestication likely began in northeastern Africa around 8,000 years ago, in regions located between the current countries of Sudan and Ethiopia (Wendorf et al. 1992). Thousands of years of selection by farmers, in a range of 
different environments, based on the variability induced by mutation, introgression and recombination, gave rise to very high morphological and genetic diversity in this multiuse cereal. Cultivated sorghums have been classified into 5 basic botanical races and 10 intermediate races based on the panicle, grain and spikelet morphology (Harlan and de Wet 1972).

Sorghum is the main food crop in Burkina Faso. Over the 1990-2004 period, the mean annual sorghum cropping area was 1.4 million ha (or $48 \%$ of the total cereal cropping area), with a mean production of 1.2 million ton of grain, or $47 \%$ of the national cereal production (MAHRH/DGPSA 2006). This production was mainly yielded by landraces belonging to the botanical race guinea (Zongo 1991; Zongo et al. 2005), for which West Africa is the main centre of diversity (Harlan 1975). These landraces are well adapted to the extensive cropping systems that prevail in Burkina Faso. The dynamic approach of farmers for managing varietal diversity involves selecting varieties with the best potential for meeting a range of different environmental characteristics and production/usage objectives. Contrary to multi-variety sorghum cropping systems that prevail in Cameroon (Barnaud et al. 2007), farmers in Burkina Faso manage their varieties separately throughout the crop cycle (sowing-harvest) and during storage. They must therefore have precise knowledge on the agronomic traits and on each variety's potential performance for a specific type of processing. Farmers in Burkina Faso must also be able to assess the physical constraints of the cropping environment. It is therefore essential to take into consideration this type of knowledge when studying the in situ diversity of crop plants (Brush 2000).

The intra-specific diversity of sorghum can be characterised based on morphological traits (Appa Rao et al. 1996; Teshome et al. 1997; Grenier et al. 2004; Barro-Kondombo et al. 2008). Enzymatic and molecular genetic markers have also recently been used for this purpose. Accessions from ex situ collections were used in most of these studies (Cui et al. 1995; de Oliveira et al. 1996; Menkir et al. 1997; Djé et al. 2000; Casa et al. 2005; Folkertsma et al. 2005; Deu et al. 2006). However, passport data were the only available documentation on them.

Data obtained from previous studies carried out with in situ collected landraces associated with cropping system surveys have enhanced the identification and assessment of evolutionary factors responsible for observed diversity structures (Djé et al. 1999; Ghebru et al. 2002; Barnaud et al. 2007). In an enzymatic marker study conducted in Burkina Faso by Ollitrault (1987), the diversity of sorghum landraces was structured into the three racial groups of guinea gambicum (by far the majority group), guinea margaritiferum and durra. The gambicum, guineense and margariferum types are subgroups of the botanical race guinea, as described by Snowden (1936). Margaritiferum is characterised by small, vitreous kernels. The agromorphological diversity of sorghum in Burkina Faso is closely linked with a north-south climatic gradient (Zongo 1991), while the genetic diversity measured by neutral markers has not shown any geographical, ethnolinguistic or environmental structuring (Ollitrault 1987; Zongo 1991; Zongo et al. 2005). Recently, Barro-Kondombo et al. (2008) have highlighted the importance of intra-village agromorphological diversity influences when comparing sorghum diversity between two regions located in different agroclimatic zones in Burkina Faso.

In many sub-Saharan countries where rainfall levels have been declining since the 1970s, the intensification of cash crops and the development of formal seed programmes could have a negative impact on the genetic diversity of crops grown in traditional agrosystems. In areas with the highest rainfall levels, sorghum is now being cropped on the least fertile soils due to the success of cotton cropping in rotation with maize, so varieties that were formerly grown on the most fertile soils are now gradually being abandoned.

Here, we present the results of an analysis of the diversity of 124 sorghum landraces from three regions of Burkina Faso (Boucle du Mouhoun, Centre-Ouest and Centre-Nord). Geo-referenced landraces were sampled and information was collected on cropping systems and on how each variety is generally used while agromorphological traits and hypervariable microsatellite markers were used for landrace descriptions. The aim was to identify and to characterise the main sorghum diversity structures in the study area, to draw up priorities for in situ conservation of sorghum landraces and to define breeding strategies that will accommodate increased yields, adaptation to heterogeneous environments and preservation of sorghum diversity in Burkina Faso.

\section{Materials and methods}

\section{Sorghum landrace collection}

Sorghum landraces were collected in 2003 and 2004 in three regions of Burkina Faso, i.e. Boucle du Mouhoun, Centre-Ouest and Centre-Nord (Fig. 1), according to the method described by Christinck et al. (2000). These regions span the following climatic zones: sub-Sahelian (isohyets 500-700 mm), northern Sudanian (isohyets 700$900 \mathrm{~mm}$ ), and southern Sudanian (isohyets 900$1,100 \mathrm{~mm}$ ). Ten villages per region were surveyed. In each of these villages, one sample of each variety recognised as morphologically different by farmers during a meeting group (gathering 10-50 farmers according to village) was 
Fig. 1 Climatic zones of Burkina Faso (Guinko 1984), and geographical locations of the surveyed villages (territorial administration)

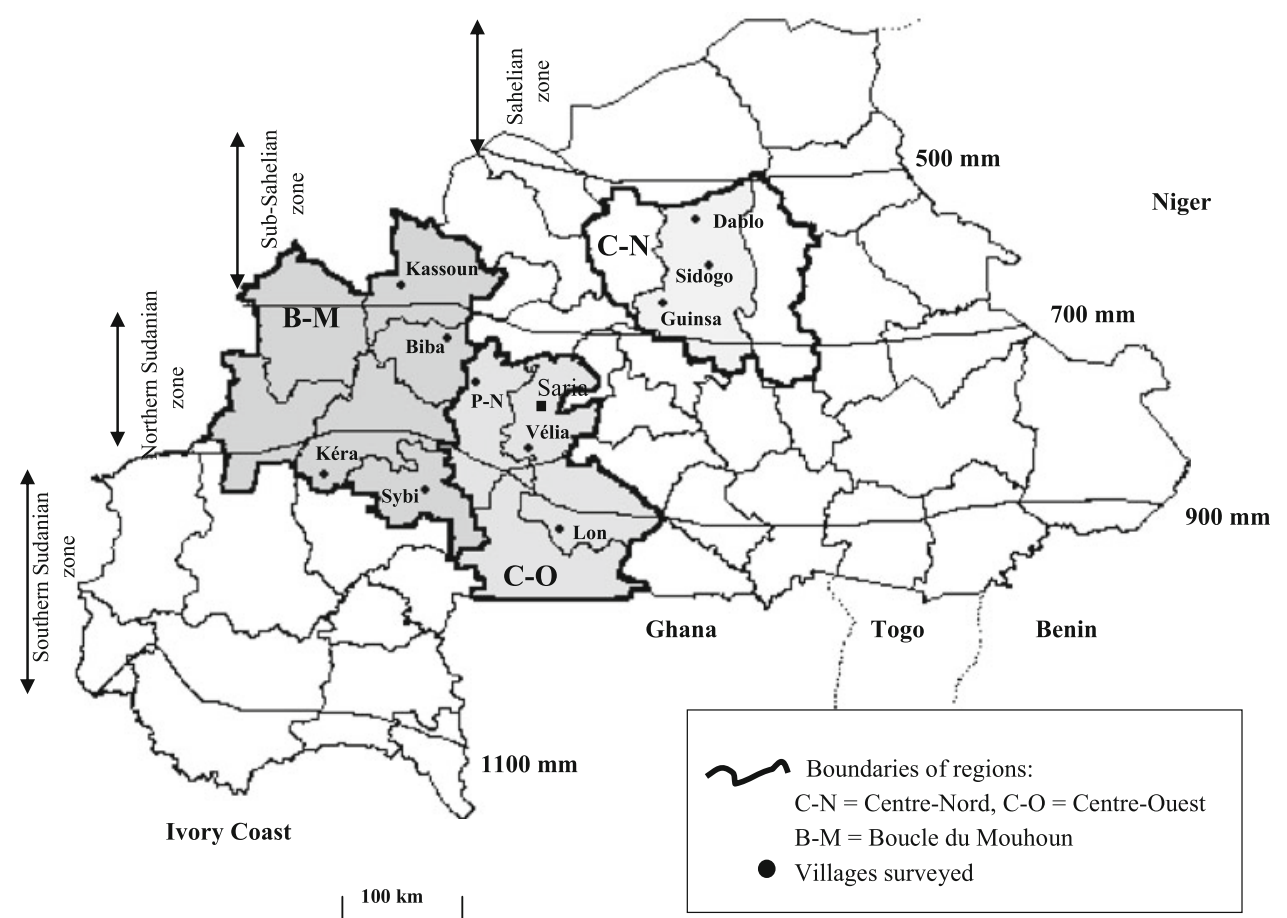

collected. Varieties with a different phenotype had different names except in rare cases. Each sample was provided by a single farmer. Samples consisted of a maximum of 25 panicles per variety supplied by the donating farmer. Otherwise, the number of available panicles was sampled, or $1 \mathrm{~kg}$ of seed was collected if threshing had already been carried out.

Sorghum racial and agromorphological characterisation

Ten of the 30 villages surveyed were chosen to represent the climatic and ethnic environmental diversity, for a total sample of 124 varieties (Table 1). Agromorphological characterisation of these varieties was conducted during the 2005 and 2006 rainy seasons at the INERA research station at Saria, where the mean rainfall level over the 1987-2006 periods was $831 \mathrm{~mm}$. The varietal trial was repeated by two sowings on July 2 and 26 in 2005 and one sowing on July 6 in 2006.

The plant material was assessed using an alpha-lattice experimental design (Patterson and Williams 1976) with three repetitions, 16 blocks with 8 landrace varieties per repetition, while randomly including four control varieties (two caudatum varieties, i.e. IS 1686 and SSM 275, and two guinea gambicum varieties, i.e. S29 and Kapelga). For each variety, all plots included two $3 \mathrm{~m}$ long rows, with $80 \mathrm{~cm}$ between rows and $20 \mathrm{~cm}$ between planting holes in the row, for 32 planting holes per plot.

The plots were thinned to one plant per planting hole around 10 days after emergence. Planting holes in which seeds had not germinated were resown with an easily identifiable variety to limit intra-plot environmental heterogeneity. Twenty-eight traits were measured on the plots or on five randomly chosen plants per plot. There were 17 qualitative traits: vigour at emergence $(\mathrm{Ve})$, coleoptile colour $(\mathrm{Cc})$, leaf anthocyanin pigmentation (Lap), panicle compactness (Pc), pedicellate spikelet length (Psl) and persistence (Psp), glume length (Gl) and opening (Go), awn (Aw), kernel shape (Ks), kernel rotation (Kr), glume colour $(\mathrm{Gc})$, kernel colour $(\mathrm{Kc})$, anthocyanin spots on kernels (Ask), glume adherence $(\mathrm{Ga})$, seed coat or testa $(\mathrm{Sc})$ and kernel vitreousness (Kv) scored according to the IBPGR scale (IBPGR/ICRISAT 1993). Eleven quantitative traits were measured: except for the duration from sowing to $50 \%$ heading (Dsh) and the photoperiod response coefficient $(\mathrm{K})$ established on the plot, the plant height $(\mathrm{Ph})$, leaf number ( $\mathrm{Ln})$, length (Ll) and width (Lw) of the third leaf under the panicle, number of effective tillers (Net), panicle length $(\mathrm{Pl})$, panicle weight $(\mathrm{Pw})$, harvested seed weight (Hsw) and 1,000-seed weight $(1,000-\mathrm{Sw})$ were measured on five plants per plot. Finally, varieties were racially characterised according to the classification of Harlan and de Wet (1972).

\section{DNA extraction and genotyping}

Sorghum seeds were germinated in a greenhouse. For each of the 124 varieties targeted for agromorphological characterisation, DNA was extracted from leaves collected from one seedling (8-9 leaf stage, $\sim 4$ weeks old) according to 
Table 1 Characterisation of villages and varieties surveyed per village

\begin{tabular}{|c|c|c|c|c|c|c|c|c|}
\hline $\begin{array}{l}\text { Surveyed } \\
\text { zones }\end{array}$ & Regions & $\begin{array}{l}\text { Surveyed } \\
\text { villages }\end{array}$ & Latitude & $\begin{array}{l}\text { Ethnic groups } \\
\text { that supplied the } \\
\text { characterised varieties }\end{array}$ & $\begin{array}{l}\text { Number of } \\
\text { varieties } \\
\text { collected } \\
\text { per village }\end{array}$ & $\begin{array}{l}\text { Age of } \\
\text { varieties in } \\
\text { the village }\end{array}$ & $\begin{array}{l}\text { Botanical } \\
\text { type found } \\
\text { per village }\end{array}$ & $\begin{array}{l}\text { Type of fields } \\
\text { where varieties } \\
\text { were cultivated }\end{array}$ \\
\hline \multirow{2}{*}{$\begin{array}{l}\text { Sub-Sahelian } \\
\qquad(500-700 \mathrm{~mm})\end{array}$} & Centre-Nord & Dablo & $13^{\circ} 4$ & Mossi & 12 & (8a 4in) & $\mathrm{gg}, \mathrm{db}, \mathrm{i}$ & $\mathrm{b}+$ \\
\hline & Centre-Nord & Guinsa & $13^{\circ} 6$ & Mossi & 15 & (2a 13in) & $\mathrm{gg}, \mathrm{ma}, \mathrm{i}$ & $\mathrm{b}+$ \\
\hline \multirow[t]{2}{*}{49 landraces } & Centre-Nord & Sidogo & $13^{\circ} 19$ & Mossi & 14 & (6a 8in) & $\mathrm{gg}, \mathrm{i}$ & $\mathrm{c}+, \mathrm{b}, \mathrm{m}$ \\
\hline & Boucle du Mouhoun & Kassoum & $12^{\circ} 9$ & Samo & 8 & (2a 6in) & gg, ma & $\mathrm{b}+$ \\
\hline \multirow{2}{*}{$\begin{array}{l}\text { Northern Sudanian } \\
\text { (700-900 mm) }\end{array}$} & Boucle du Mouhoun & Biba & $12^{\circ} 6$ & Samo and Peul & 9 & (2a 7in) & $\mathrm{gg}, \mathrm{i}$ & $\mathrm{b}+, \mathrm{c}$ \\
\hline & Centre-Ouest & Velia & $12^{\circ} 1$ & Mossi & 14 & (6a 8in) & $\mathrm{gg}, \mathrm{ma}$ & $\mathrm{m}+, \mathrm{b}$ \\
\hline 53 landraces & Centre-Ouest & Pouni-Nord & $12^{\circ} 28$ & Lyélé & 30 & (3a 27in) & gg & $\mathrm{b}+, \mathrm{c}, \mathrm{m}$ \\
\hline \multirow{2}{*}{$\begin{array}{l}\text { Southern Sudanian } \\
(900-1,100 \mathrm{~mm})\end{array}$} & Boucle du Mouhoun & Sybi & $11^{\circ} 8$ & Lyélé, Mossi, Marka, & 6 & (0a 6in) & $\mathrm{gg}$ & $\mathrm{b}+, \mathrm{c}$ \\
\hline & Boucle du Mouhoun & Kéra & $11^{\circ} 9$ & Bwaba and Mossi & 10 & (5a 5 in $)$ & $\mathrm{gg}, \mathrm{ma}, \mathrm{b}$ & $\mathrm{b}+, \mathrm{c}$ \\
\hline 22 landraces & Centre-Ouest & Lon & $11^{\circ} 5$ & Nuuni and Mossi & 6 & (1a $5 \operatorname{in})$ & $\mathrm{gg}$ & $\mathrm{b}+, \mathrm{c}, \mathrm{m}$ \\
\hline
\end{tabular}

$a$ ancestral varieties (grown for over 20 years in the village); a total of 35 varieties, in varieties introduced over the last 20 years preceding the survey; a total of 89 varieties, $g g$ guinea gambicum, ma guinea margaritiferum, $d b$ durra bicolor, $b$ bicolor, $i$ indeterminate, $c$ compound, $b$ bush, $m$ mixed: sown in compound and bush fields, + the majority type in the village

the modified CTAB procedure (Barnaud et al. 2007). PCRs were performed in a $20 \mu \mathrm{l}$ final volume containing $5 \mu \mathrm{l}$ DNA $(5 \mathrm{ng} / \mu \mathrm{l}), 0.2 \mu \mathrm{M}$ reverse primer, $0.2 \mu \mathrm{M} 5^{\prime}$-endlabelled $\gamma\left[{ }^{33} \mathrm{P}\right]$ ATP forward primer, $2 \mu \mathrm{l} 10 \times$ buffer, $200 \mu \mathrm{M}$ dNTPs and $0.1 \mathrm{U} / \mu \mathrm{l}$ Taq polymerase). Thirty-five amplification cycles were conducted, with an initial denaturation phase at $94^{\circ} \mathrm{C}(4 \mathrm{~min})$, followed by a first series of 10 cycles with denaturation at $94^{\circ} \mathrm{C}(45 \mathrm{~s})$, hybridization at $\mathrm{TM}+5^{\circ} \mathrm{C}(1 \mathrm{~min})$, with a reduction of $0.5^{\circ} \mathrm{C}$ per cycle, elongation at $72^{\circ} \mathrm{C}(1 \mathrm{~min} 30 \mathrm{~s})$, and a second series of 25 cycles with denaturation at $94^{\circ} \mathrm{C}(45 \mathrm{~s}), \mathrm{TM}(1 \mathrm{~min}), 72^{\circ} \mathrm{C}$ ( $1 \mathrm{~min} 30 \mathrm{~s}$ ), and final elongation at $72^{\circ} \mathrm{C}$ for $4 \mathrm{~min}$. The amplification products were then submitted to electrophoresis at $60 \mathrm{~W}$ in polyacrylamide denaturing gel at $5 \%$ concentration in migration buffer (TBE $1 \times)$. Amplification products of microsatellite pairs differing in product size were separated on the same gel by loading the lighter at time $t$ and the heavier at time $t+15 \mathrm{~min}$. The gels were dried and exposed to autoradiography films (LifeRay, XDA plus) for 48-72 h. Alleles were identified via three controls that were included in each gel. The controls were developed by the Generation Challenge Program, with each being a DNA mixture obtained from three or four varieties (http://sat.cirad.fr/sat/sorghum_SSR_kit/). Twenty-nine microsatellite markers described and mapped (Brown et al. 1996; Taramino et al. 1997; Bhattramakki et al. 2000; Kong et al. 2000; Schloss et al. 2002), or presented on the website http://sat.cirad.fr/sat/sorghum_SSR_kit/ (gpsb markers developed by CIRAD and selected by the Generation Challenge Programme) were used for the genotyping (Table 2).
Statistical analysis of agromorphological data

The statistical analysis was conducted on data of the trials sown on 2 July in 2005 and 6 July in 2006. Variance estimations and tests of effects were carried out on quantitative traits using the REML method implemented in HPMIXED procedure of SAS software, version 9.2 TS2M0, according to the following linear hierarchical mixed model:

$$
\begin{aligned}
Y_{i j k l m n}= & \mu+\alpha_{i}+\beta_{j}+(\alpha \beta)_{i j}+c_{j k}+(\alpha c)_{i j k}+d_{j k l} \\
& +(\alpha d)_{i j k l}+f_{i m}+g_{i m n}+e_{i j k l m n} .
\end{aligned}
$$

where Greek letters are for fixed effects and Latin letters are for random effects. $\mu$ is the overall mean; $\alpha_{i}$ is the effect of year $i ; \beta_{j}$ is the effect of zone $j ;(\alpha \beta)_{i j}$ is the year $\times$ zone interaction; $c_{j k}$ is the effect of village $k$ nested within zone $j ;(\alpha c)_{i j k}$ is its interaction with year $i ; d_{j k l}$ is the effect of variety $l$ nested within village $k$ within zone $j ;(\alpha d)_{i j k l}$ is its interaction with year $i ; f_{i m}$ is the effect of replicate $m$ in year $i ; g_{i m n}$ is the effect of block $n$ within this replicate; and $e_{i j k l m n}$ is the residual error.

This model was chosen in order to estimate the contribution of village origin to the variance of the variety effect, and also the contribution of year $\times$ village interaction to the total year $\times$ variety interaction.

The effective tillering variable (Net), which had a nonnormal distribution, was not used in this analysis. Moreover, the coefficient of response to photoperiod $(K)$, whose calculation involved the two trials sowed at two different dates in 2005, was also not used. For each variety, the $K$ coefficient was computed as: 
Table 2 Microsatellite loci and genetic diversity parameters estimated from 29 loci

\begin{tabular}{|c|c|c|c|c|c|}
\hline Locus & $\begin{array}{l}\text { Number of microsatellite } \\
\text { motif repetitions }\end{array}$ & Chromosome & $\begin{array}{l}\text { Range of allele size in } \\
\text { base pairs in present study }\end{array}$ & $A$ & $\mathrm{He}$ \\
\hline gpsb067 & $(\mathrm{GT})_{10}$ & 8 & $170-182$ & 6 & 0.41 \\
\hline gpsb089 & $(\mathrm{TG})_{9}$ & 1 & $165-173$ & 4 & 0.58 \\
\hline gpsb123 & $(\mathrm{AC})_{7+}(\mathrm{GA})_{5}$ & 8 & $288-296$ & 4 & 0.10 \\
\hline gpsb148 & $(\mathrm{TC})_{3}+(\mathrm{CA})_{5}$ & 7 & $133-147$ & 4 & 0.54 \\
\hline gpsb151 & $(\mathrm{CT})_{12}$ & 4 & $104-112$ & 5 & 0.68 \\
\hline SbAGB02 & $(\mathrm{AG})_{35}$ & 7 & $096-116$ & 4 & 0.06 \\
\hline Sb4-72 (Xgap72) & $(\mathrm{AG})_{16}$ & 6 & $183-197$ & 7 & 0.39 \\
\hline Sb5-206 (Xgap206) & $(\mathrm{AC})_{13}(\mathrm{AG})_{20}$ & 9 & $108-146$ & 6 & 0.33 \\
\hline Sb6-84 (Xgap84) & $(\mathrm{AG})_{14}$ & 2 & $181-199$ & 6 & 0.33 \\
\hline Xcup02 & $(\mathrm{GCA})_{6}$ & 9 & $186-204$ & 5 & 0.68 \\
\hline Xcup07 & $(\mathrm{CAA})_{8}$ & 10 & $251-269$ & 7 & 0.67 \\
\hline Xcup11 & $(\mathrm{GCTA})_{4}$ & 3 & $165-172$ & 2 & 0.12 \\
\hline Xcup14 & $(\mathrm{AG})_{10}$ & 3 & $211-233$ & 7 & 0.37 \\
\hline Xcup61 & $(\mathrm{CAG})_{7}$ & 3 & 198-201 & 2 & 0.36 \\
\hline Xcup62 & $(\mathrm{GAA})_{6}$ & 1 & $190-193$ & 2 & 0.02 \\
\hline Xcup63 & $(\text { GGATGC })_{4}$ & 2 & $139-145$ & 2 & 0.48 \\
\hline Xtxp10 & $(\mathrm{CT})_{14}$ & 9 & $133-153$ & 4 & 0.07 \\
\hline Xtxp15 & $(\mathrm{TC})_{16}$ & 5 & $201-215$ & 6 & 0.30 \\
\hline Xtxp40 & $(\mathrm{GGA})_{7}$ & 7 & $126-141$ & 6 & 0.16 \\
\hline Xtxp57 & $(\mathrm{GT})_{21}$ & 6 & $223-249$ & 7 & 0.59 \\
\hline Xtxp65 & $(\mathrm{ACC})_{4}(\mathrm{CCA})_{3} \mathrm{CG}(\mathrm{CT})_{8}$ & 5 & $122-136$ & 5 & 0.63 \\
\hline Xtxp114 & $(\mathrm{AGG})_{8}$ & 3 & $211-217$ & 3 & 0.21 \\
\hline Xtxp136 & $(\mathrm{GCA})_{5}$ & 5 & $240-246$ & 3 & 0.07 \\
\hline Xtxp145 & $(\mathrm{AG})_{22}$ & 6 & $206-214$ & 4 & 0.46 \\
\hline Xtxp278 & $(\mathrm{TTG})_{12}$ & 7 & $243-252$ & 3 & 0.29 \\
\hline Xtxp289 & $(\mathrm{CCT})_{16}(\mathrm{AGG})_{6}$ & 9 & $263-275$ & 4 & 0.19 \\
\hline Xtxp295 & $(\mathrm{TC})_{19}$ & 7 & $143-199$ & 17 & 0.84 \\
\hline Xtxp320 & $(\mathrm{AAG})_{20}$ & 10 & $257-284$ & 6 & 0.57 \\
\hline Xtxp339 & $(\mathrm{GGA})_{7}$ & 9 & $191-200$ & 2 & 0.07 \\
\hline
\end{tabular}

Chromosome is nomenclature of Kim et al. (2005)

$A$ is number of alleles per locus, $\mathrm{He}$ is gene diversity

$K=\frac{D \operatorname{sh} 1-D \operatorname{sh} 2}{D a t S 2-D a t S 1}$

with Dsh1 and Dsh2 the mean duration in days from sowing to heading for the first and second sowing dates in 2005, respectively, and DatS1 and DatS2 the first and second 2005 sowing days in Julian days, where $K$ is expected to range from 0 (no shortening of the vegetative phase observed when sowing was delayed when the days were shortest) and 1 (duration shortening equal to the sowing delay) (Traoré et al. 2000).

The nine quantitative variables of the variance analyses (Dsh, Ph, Ln, Ll, Lw, Pl, Pw, Hsw, 1,000-Sw) and one qualitative variable $(K v)$ selected after eliminating all nonGaussian or categorical variables were used as input data for a hierarchical cluster analysis (HCA) (Benzecri 1984), built on the basis of the Euclidian distance according to the aggregation criterion of Ward (1963). XL-STAT-PRO software (version 7.5 1995-2000) was used for this analysis (Fahmy 1999).

Statistical analysis of microsatellite data

Genetic Polymorphism was measured by the allelic diversity $(A)$, the allelic richness $(R s)$, which is an unbiased estimate of the number of alleles expected per locus irrespective of the sample size (El Mousadik and Petit 1996), the observed heterozygosity rate $(\mathrm{Ho})$ and the unbiased expected heterozygosity (Nei 1987) also named gene diversity $(\mathrm{He})$. The genetic differentiation $\left(F_{\mathrm{ST}}\right)$ between two variety groups was determined using the estimators of 
Weir and Cockerham (1984). All of these parameters were calculated with FSTAT software (version 2.9.3) (Goudet 2001). Rs values and the expected heterozygosities were compared between groups using a Wilcoxon signed-rank test (Wilcoxon 1945).

A molecular variance analysis (AMOVA) was performed using Arlequin software (version 3.0) (Excoffier and Schneider 2005). Genetic dissimilarities were calculated using the simple matching index (Sokal and Michener 1958), which in turn was used for hierarchical classification using the Neighbour-joining method (Saitou and Nei 1987). Robustness was assessed by bootstraps $(1,000$ repetitions) using DARwin software, version 5.0.150 (Perrier and Jacquemoud-Collet 2006). A Mantel test (1967) was performed on genetic dissimilarity and geographical distance matrices to compare correlations between morphological and genetic structures.

\section{Results}

Sorghum varietal diversity in ten villages

From 6 to 30 local varieties were collected in the 10 surveyed villages (Table 1). Greater varietal diversity was noted in sub-Sahelian and northern Sudanian zones with the least rainfall, with 12.3 and 17.7 varieties, respectively, collected per village as compared to the southern Sudanian zone where only 7.3 varieties were collected. The number of varieties was especially high in the village of Pouni-Nord (30 varieties).

White kernel varieties outnumbered all other varieties everywhere. They are mainly grown for use in the preparation of tô (staple food of rural inhabitants), but also to an increasing extent for malting. Red kernel varieties were grown on smaller areas, essentially to bridge gaps between harvests and for the preparation of dolo, a local highly popular beer that is served during traditional ceremonies. We also noted an overriding number of varieties that had been introduced by seed exchange between farmers from neighbour villages within the last 20 years preceding the collection (89 varieties), as compared to the ancestral varieties (35 varieties) that were mainly kept for traditional purposes (pharmacopoeia and ancient rites). From 43 to $67 \%$ of all varieties grown in the villages of Dablo, Kéra, Sidogo and Velia were ancestral varieties.

We noted that the same farming practices and types of varieties were used in each village. Sorghum was often intercropped with cowpeas [Vigna unguiculata (L.)] or millet [Pennisetum glaucum (L.) R. Br.], and seldom with other crops. The different varieties grown were adapted to different cropping areas and soil types in relation to their phenological features (compound plots and bush fields at different toposequence levels).

Sorghum racial and agromorphological structures

The racial characterisation revealed that $94.4 \%$ of the 124 collected varieties belonged to the guinea race, $0.8 \%$ to the bicolor race, $0.8 \%$ to the durra-bicolor race and $4.0 \%$ could not be classified clearly (racially indeterminate form). Among the guinea landraces, $96.6 \%$ belonged to the gambicum type and $3.4 \%$ to the margaritiferum type.

Most of the collected varieties had white kernels (74.2\%), without testa $(83.9 \%)$, and were vitreous (vitreousness score ranging from 1.5 to 3 ). The remaining varieties had orange (13.7\%) and red kernels (12.1\%). The length of the sowing-heading duration ranged from 58.6 to 85.5 days for materials from the sub-Sahelian zone, from 68.2 to 86.1 days for those from the northern Sudanian zone, and from 72.0 to 93.7 days for those from the southern Sudanian zone. The zonal mean sowing-heading interval per zone increased significantly $(P<0.01)$ over a north to south gradient (75.3, 79.1 and 85.4 days, respectively). Early varieties (sowing-heading interval $\leq 76$ days), intermediate varieties (76-85 days) and late varieties (interval $>85$ days) represented 28.2, 58.9 and $12.9 \%$ of the material, respectively. Red kernel varieties were significantly $(P<0.01)$ earlier (sowing-heading interval 73.8 days) than the white to orange kernel varieties (79.4 days), and the mean sowing-heading interval comparison test results indicated significant differences $(P<0.01) .12 .1 \%$ of the varieties were moderately photoperiod sensitive $(0.4 \leq K \leq 0.5)$, whereas $81.5 \%$ were highly sensitive $(0.5<K \leq 0.8)$ and $6.4 \%$ were even more sensitive $(0.8<K \leq 1)$.

Regarding the fixed effects, the type III tests performed on the nine quantitative variables revealed a highly significant year effect for all studied variables and less frequently a significant zone effect (Table 3 ). The interaction year $\times$ zone was not significant except for the $1,000-\mathrm{Sw}$ variable. With respect to the random effects, the variance of the village origin effect was always less than a third of that of the variety within village effect. The analog comparison between year $\times$ village origin and year $\times$ variety within village interactions was less stable, however, the latter again dominated except solely for Lw (Table 3).

The hierarchical cluster analysis (Fig. 2) identified five main variety groups, mainly distinguished by crop duration, plant height, 1,000-seed weight and kernel vitreousness traits. Group A included the late-maturing and tall varieties (7 varieties) with small and highly vitreous grain. Group E included the early-maturing and short varieties (17 varieties) with big grain and floury kernel structure. 


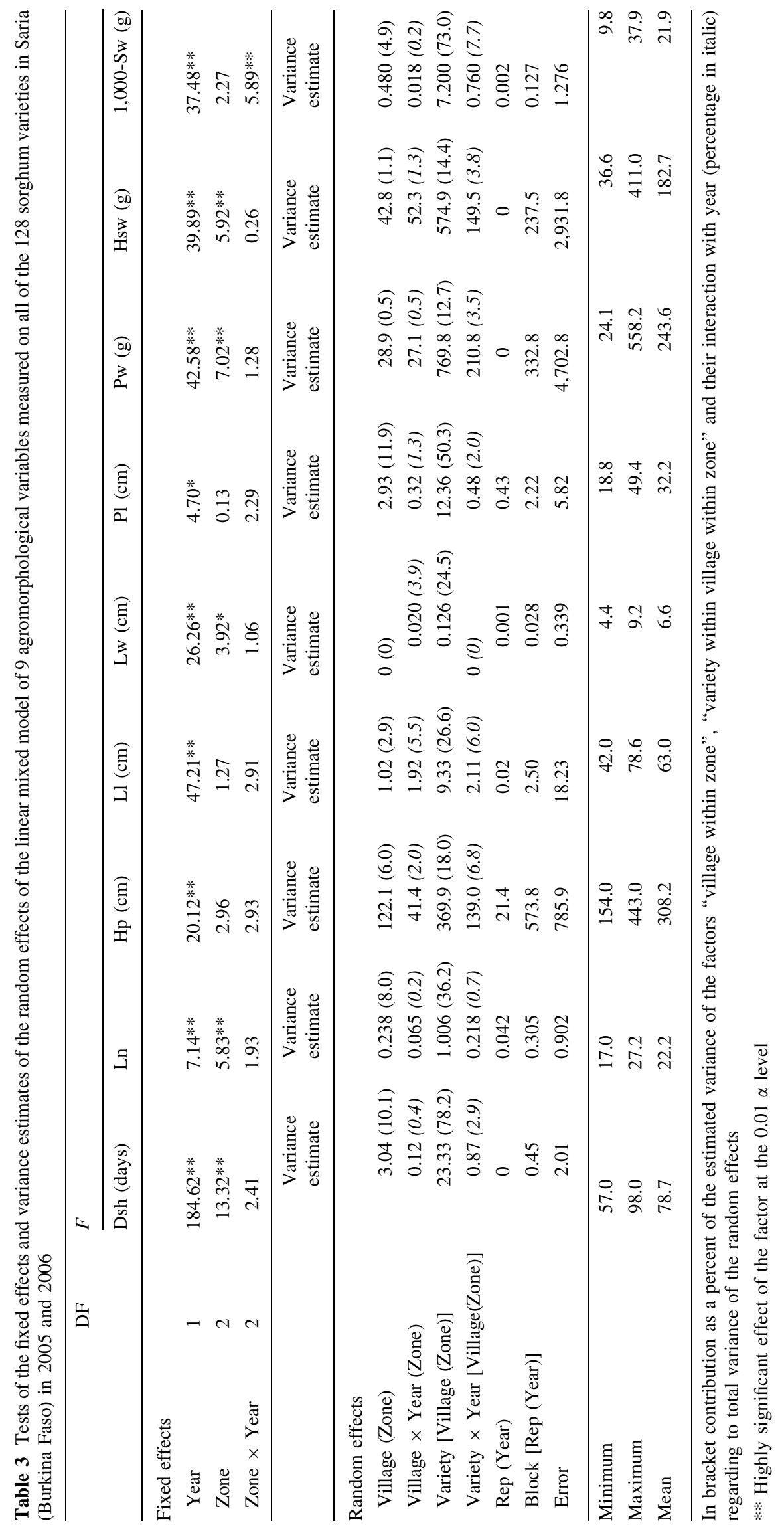


Fig. 2 Agromorphological structure of 124 sorghum landraces determined by hierarchical cluster analysis (HCA) according to Ward's algorithm

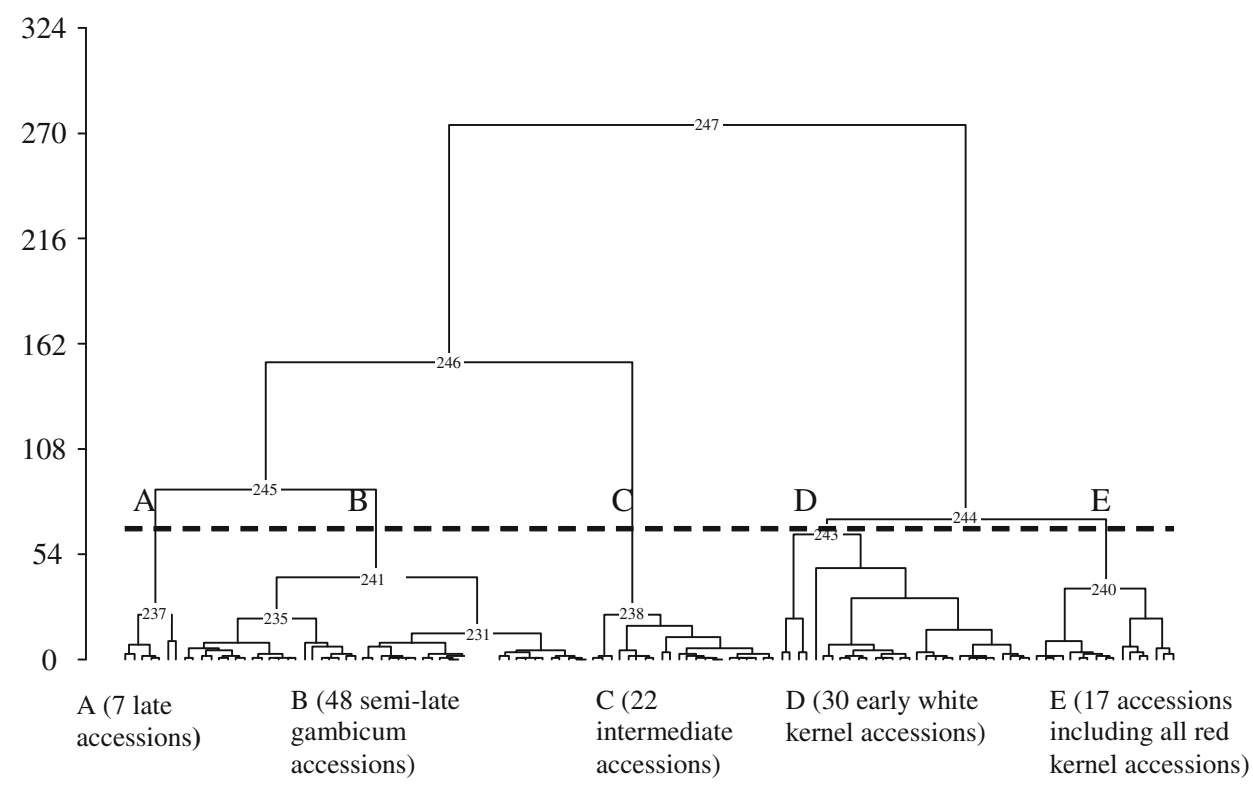

Group B (48 varieties), group C (22 varieties) and group D (30 varieties) were characterised by various intermediate classes of the discriminating variables. It is striking that group E contained all 15 red kernel varieties (guinea or indeterminate race) along with two white kernel gambicum varieties. The four margaritiferum varieties were equally distributed across groups A and D according to their vegetative phase.

Genetic polymorphism

Genetic parameters based on 29 microsatellite loci were calculated for all 124 varieties (Table 2). Six loci were monomorphic at the $95 \%$ threshold, i.e. gpsb123, SbAGB02, Xcup62, Xtxp10, Xtxp136 and Xtxp339. The Xtxp40 locus had a supposed high frequency null allele (11 varieties showed no alleles at this locus, despite the genotyping repetitions) likely because of an absence of amplification due to mutations in flanking regions (Stachel et al. 2000). Thus, the six monomorphic loci and the locus Xtxp40 were excluded from the final analysis of population structure with the DARwin software.

With all 29 loci taken into account, total number of alleles detected reached 143 with 2-17 alleles per locus with a mean number 4.9 alleles per locus. The allelic richness $R_{\mathrm{s}}$ ranged from 1.1 to 5.5 per locus and 1.8 to 2.5 per village (Table 4). The Dablo, Kéra and Guinsa varieties showed the highest allelic richness and the Pouni-Nord varieties showed the lowest allelic richness. All Wilcoxon tests confirmed the reduced allelic richness in Pouni-Nord and the higher allelic richness in Dablo.
Table 4 Genetic diversity and differentiation parameters according to different factors

\begin{tabular}{|c|c|c|c|c|c|c|}
\hline & $N$ & $A$ & $R s$ & $H_{O}$ & $\mathrm{He}$ & $F_{\mathrm{ST}}$ \\
\hline Villages & 124 & & & & & $0.06^{*}$ \\
\hline Dablo & 12 & 3.0 & 2.5 & 0.04 & 0.38 & \\
\hline Guinsa & 15 & 3.0 & 2.4 & 0.05 & 0.36 & \\
\hline Sidogo & 14 & 2.8 & 2.2 & 0.11 & 0.35 & \\
\hline Kassoum & 8 & 2.2 & 2.1 & 0.06 & 0.36 & \\
\hline Biba & 9 & 2.1 & 2.0 & 0.02 & 0.29 & \\
\hline Velia & 14 & 2.6 & 2.2 & 0.07 & 0.35 & \\
\hline Pouni-Nord & 30 & 2.4 & 1.8 & 0.09 & 0.23 & \\
\hline Sybi & 6 & 2.0 & 2.0 & 0.04 & 0.33 & \\
\hline Kéra & 10 & 2.8 & 2.5 & 0.04 & 0.40 & \\
\hline Lon & 6 & 1.9 & 1.8 & 0.12 & 0.27 & \\
\hline Climatic zones & 124 & & & & & $0.04 *$ \\
\hline Sub-Sahelian zone & 49 & 4.1 & 3.7 & 0.06 & 0.38 & \\
\hline Northern Sudanian zone & 53 & 3.9 & 3.3 & 0.07 & 0.35 & \\
\hline Southern Sudanian zone & 22 & 2.1 & 2.1 & 0.06 & 0.23 & \\
\hline Origins & 124 & & & & & 0.01 \\
\hline Ancestral & 35 & 3.8 & 3.7 & 0.06 & 0.38 & \\
\hline Recent & 89 & 4.2 & 3.5 & 0.07 & 0.34 & \\
\hline Kernel types & 124 & & & & & $0.08^{*}$ \\
\hline White & 91 & 4.2 & 3.0 & 0.06 & 0.33 & \\
\hline Orange & 17 & 2.8 & 2.8 & 0.10 & 0.33 & \\
\hline Red & 16 & 3.1 & 3.1 & 0.06 & 0.35 & \\
\hline All & 124 & 4.9 & 2.3 & 0.06 & 0.37 & \\
\hline
\end{tabular}

$N$ number of varieties, $A$ mean number of alleles per locus, $R s$ allelic richness, $\mathrm{Ho}$ observed heterozygosity, $\mathrm{He}$ expected heterozygosity or gene diversity, $F_{\mathrm{ST}}$ genetic differentiation among groups

* Significant at $P<0.05$ 
The total gene diversity $(\mathrm{He})$ for overall population reached 0.37 but showed different values among the villages $(0.23 \leq H e \leq 0.40)$ (Table 4). It was higher in the sub-Sahelian zone $(0.38)$ than in the northern $(0.35)$ and southern Sudanian $(0.23)$ zones.

\section{Genetic structure}

The total genetic differentiation between villages was low but significant $\left(F_{\mathrm{ST}}=0.06, P<0.05\right.$, with a confidence interval of $0.037-0.086$ ). When the $F_{\mathrm{ST}}$ values were assessed by pairs of villages, only Pouni-Nord was significantly different from the other villages, with $F_{\mathrm{ST}}$ values ranging from 0.07 to 0.16 , but this result should be considered with caution due to the marked differences in the number of varieties per village.

The genetic structure between rainfall zones was also low $\left(F_{\mathrm{ST}}=0.04\right)$ but significant, with a confidence interval of 0.016-0.069. The pairwise $F_{\text {ST }}$ values showed lower differentiation between the sub-Sahelian and northern Sudanian zones $\left(F_{\mathrm{ST}}=0.02\right)$ than between the two more contrasted southern Sudanian and sub-Sahelian zones $\left(F_{\mathrm{ST}}=0.10\right)$. Moreover, no structuring was noted between ancestral varieties and introduced varieties $\left(F_{\mathrm{ST}}=0.01\right)$.

Genetic differentiation was highest and significant between varietal types with different kernel colours $\left(F_{\mathrm{ST}}=0.08, P<0.05\right.$, with a confidence interval of 0.043-0.113). Genetic differentiation was not significant between white kernel varieties and orange kernel varieties $\left(F_{\mathrm{ST}}=0.02\right)$. However, these two groups differed significantly from red kernel varieties $\left(0.10 \leq F_{\mathrm{ST}} \leq 0.13\right)$. The Xtxp145 and gpsb067 loci markedly differentiated the red kernel varieties from the other varieties $\left(F_{\mathrm{ST}}=0.22\right.$ and 0.35 , respectively).

The molecular variance analysis indicated that $4.5 \%$ of the genetic variability could be explained by differences between rainfall zones, $5.8 \%$ by differences between villages in the same zone, and $89.7 \%$ by differences between varieties within the same village.

The Neighbour-joining tree based on genetic dissimilarities measured using SSR marker allelic data across 22 loci revealed three groups of varieties (Fig. 3). The first and second groups included individuals that all belonged to the botanical type guinea gambicum. $77 \%$ of the varieties collected from the village of Pouni-Nord were in group 1 and they represented $40 \%$ of all varieties of this group. The third group included all the varieties which are not gambicum. It also included the red varieties (gambicum or indeterminate race) for the most part and some white kernel gambicum varieties.

Figure 3 also compared the three groups determined based on genetic dissimilarities with the five groups derived from the morphological trait classification. All red kernel varieties of phenotype group $\mathrm{E}$ were in genetic group 3. The results of the Mantel correlation test carried out on genetic and agromorphological dissimilarity matrices were significant $(r=0.45, P<0.01)$.

\section{Discussion}

Sorghum diversity within villages

It was found that farmers belonging to the same village in Burkina Faso cultivate a broad range of sorghum varieties in order to address a high diversity of cropping environments as well as to minimise risks and optimise harvesting. This strategy is clearly illustrated by the fact that red kernel sorghum types (earlier) are cropped in compound plots while white kernel varieties (later) are cropped in bush fields. Many sorghum varieties are grown for beer brewing, usually for traditional secular animistic purposes, as is also the practise in several other West African countries (Barnaud et al. 2007). Surveys carried out during sorghum collection highlighted the importance of traditional beliefs, such as the need to maintain some varieties cultivated by family relatives to honour their memory. Seed is still, by and large, stored in traditional ways on farms. Tradition is, therefore, an important factor with respect to preserving sorghum genetic diversity.

\section{Sorghum agromorphological diversity}

The racial composition of sorghum varieties collected in our survey confirmed the dominance of the guinea race of the gambicum type in Burkina Faso, as already been noted by Zongo (1991). In other neighbouring countries of Nigeria and Chad, however, this racial composition differs, with the guinea race representing only 40.2 and $7.0 \%$, respectively, of all cultivated varieties (Yagoua 1994). This dominance of the guinea race in Burkina Faso could be explained by biogeographical factors. Burkina Faso is a centre of diversification of the guinea race that is well adapted to subhumid climatic conditions. Indeed, it is the only botanical race found in the southern Sudanian zone which has the highest rainfall level in Burkina Faso.

In the agromorphological structure analysis, red kernel guinea varieties clearly differed from the other guinea varieties (Fig. 2). On average, they were earlier (73.8 days) than white or orange kernel sorghum varieties (79.4 days). Moreover, the red kernel guinea varieties were found to be flourier and less photoperiod sensitive. This difference between red and white kernel sorghum varieties has already been pointed out by Barro-Kondombo et al. (2008) in a study on a larger sample of varieties from Burkina Faso. This difference is the main factor responsible for the 
Fig. 3 Neighbour-joining tree based on data for 22 polymorphic SSR loci among 124 sorghum landraces using the simple matching genetic dissimilarity index and comparison with HCA groups.

The racial origin is noted under each point: $g$ (guinea gambicum). $m$ (guinea margaritiferum) $b$ (bicolor) $d b$ (durra bicolor) $I$ (indeterminate) Group 1: light colour kernel gambicum accessions encompassing the majority of the varieties from Pouni-Nord village Group 2: light colour kernel gambicum accessions Group 3: margaritiferum, bicolor, durra-bicolor and red kernel accessions (gambicum or indeterminate race) and some white kernel gambicum accessions

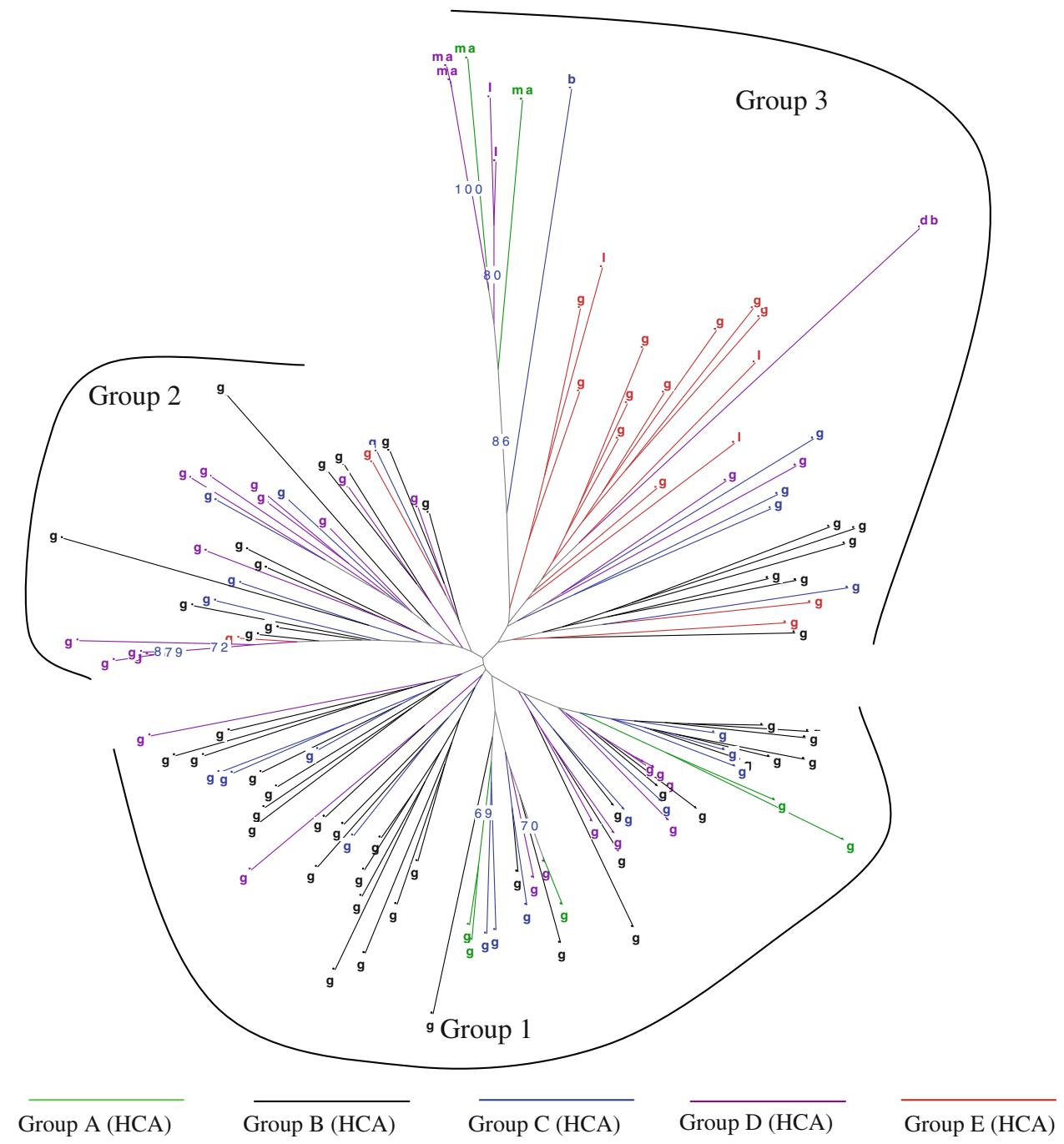

agromorphological variability structure of sorghum varieties in Burkina Faso, with botanical classification being a secondary factor.

From a varietal standpoint, the sowing-heading interval length and 1,000-seed weight were the most important traits. These traits are highly heritable and can be readily selected. They also seemed to be the most associated with climatic and crop system differences. According to previous findings (Folliard et al. 2004; Clerget et al. 2007), the sowing-heading interval, which accounts for the photoperiod sensitivity trait, should be considered the main criterion for adaptation of a sorghum variety to its cropping zone in Burkina Faso.

Finally, the $F$ tests indicated a significant year effect for all agromorphological traits (Table 3). Not surprisingly, this highlights a variety response to environmental condition. Of particular interest was the result regarding the two random factors "village within zone" and "variety within village within zone". The constant predominant contribution of the latter over the former in regard to variance of random effects clearly suggests that the range of variety diversity in a given climatic zone is more important within villages than between villages. This was quite noticeable with three variables: sowing-heading interval length, panicle length and 1,000-seed weight. These traits are of considerable importance to the village farmers when it comes to differentiating the varieties.

Sorghum diversity and genetic structure

Caution is needed when comparing the genetic diversity revealed by microsatellite markers in our study with that reported by other authors because of the different analysis tools used, as well as the size and racial composition of the samples.

Considering only genetic studies conducted with microsatellite markers, the genetic diversity parameters estimated in this study $(A=4.9$ alleles per locus, $\mathrm{He}=0.37)$ were similar to those estimated by Folkertsma et al. (2005) on a sample of guinea sorghum varieties from 
various regions worldwide. They were slightly lower than those estimated for southern African sorghum varieties (Uptmoor et al. 2003), and much lower than those estimated for Eritrean sorghum landraces (Ghebru et al. 2002) and those estimated by Deu et al. (2008) for sorghum varieties from Niger at the country scale with 27 common SSRs, i.e. countries where sorghum racial diversity is greater than in Burkina Faso. Sorghum genetic diversity seems to be associated with the botanical diversity. It is lower in Burkina Faso than in other countries or regions that have greater botanical diversity, but it clearly represents much of the genetic diversity within the botanical race guinea, confirming that Burkina Faso is biogeographically positioned at the centre of guinea sorghum diversity in West Africa (Harlan 1975; Zongo et al. 2005).

Sorghum varieties from the sub-Sahelian zone had higher genetic diversity than those of the two other climatic zones with higher rainfall and they seemed to be more differentiated (Table 4). Four non-exclusive explanations could be put forward: (1) in dry areas, genetic diversity contributes more to the resilience of cropping systems than in areas with higher rainfall, especially since there are few agricultural alternatives to sorghum and millet cropping; (2) the main factors in the reduction of genetic diversity are clearly most associated with modifications in cropping systems than with recurring drought periods. This trend was also noted by Kouressy et al. (2003) in Mali, where varietal erosion was found to be associated with the extension of cotton grown in rotations with maize in the Sudanian zone; (3) the cultural importance (ancestral rites) and popularity of traditional practices (social beliefs and pharmacopoeia associated with sorghum) are more prevalent in the Centre Nord region; and (4) there has been an increase in seed programmes coordinated by government services or NGOs in the Sahelian regions promoting varieties which are different from traditional varieties.

Genetic differentiation between climatic zones was still found to be low (0.04) (Table 4). This should be considered in relation to the common historical origin of the guinea gene pool and also likely to the high gene flows promoted by migrations of human populations (especially the Mossi) seeking more fertile land. None of the villages surveyed had a mono-ethnic structure. Moreover, seed purchases in local markets, seed exchanges in sometimes geographically wide-ranging family networks or between farmers involved in transregional extension programmes are relatively common.

A similar explanation could thus be put forward on the lack of genetic differentiation between ancestral and recent varieties (0.01). This result seems to indicate that the two types of material belonged to the same gene pool, and the introduced varieties were certainly only the result of the turnover of local varieties between villages and their mixing due to the natural allogamy of guinea sorghum landraces, with rates that may be around 20\% (Ollitrault et al. 1997).

Genetic differentiation between villages was low. The molecular variance analysis results indicated the genetic variability could only partially be explained by the climatic zone factor $(4.5 \%)$ and the village within the same climatic zone factor $(5.8 \%)$, whereas the variety in the same village was the main explanatory factor $(89.7 \%)$. Genetic diversity within a locality thus seemed to be associated with the observed agromorphological diversity in relation with the range of different uses, cropping systems and the soil-climate variability of the specific area. Few sorghum genetic diversity studies have been conducted on a local scale (Barnaud et al. 2007). It would therefore be essential to gain further insight into the local evolutionary factors involved in sorghum genetic diversity, especially the intravarietal diversity. Already our results have highlighted that diversity on a village scale may be representative of the diversity on a much broader scale, i.e. regional. However, the village of Pouni-Nord differed in terms of the number of varieties present with agromorphological and genetic traits which differed substantially from varieties of other villages, even those within the same climatic zone, as also shown by their assembly in group 1 in Fig. 3. Several hypotheses could explain the observed structuring trend: (1) the composition of the Pouni-Nord varieties panel differs highly from the composition of the other villages, both in terms of varieties from the genetic group 1 ( 77 vs. $31 \%$ in average) and red kernel varieties ( 3 vs. $15 \%$ in average); (2) Lyélé is by far the main ethnic group in the village and it is socioculturally isolated. Apart from marital ties, this population is not very open to exchanges and there is no inter-village emigration apart from some outmigration to large towns.

Finally, kernel colour was found to be the main genetic differentiation factor, with a significant $F_{\text {ST }}$ of 0.08 . Red kernel sorghum varieties grown for beer brewing, which were clearly identified by a morphological classification group (group E in Fig. 2), were all in the same genetic group and differed quite markedly from other sorghum varieties of the botanical race guinea gambicum (Fig. 3). They contributed to the significant positive correlation that was established in the Mantel test between the agromorphological and genetic diversity. Red sorghum varieties for beer brewing are generally earlier and grown on small areas, often in compound plots. Genetic drift and reproductive isolation are factors likely involved in their observed genetic diversity with respect to other guinea gambicum varieties. In addition, morphologically detectable first generation hybrids might be more easily counterselected by farmers, thus bolstering the phenological barriers to inter-varietal introgression. 
Implications for sorghum conservation and improvement programmes

This study highlighted several interesting points that would be useful for sorghum breeding programmes in Burkina Faso. The geographical structure of local climatic adaptation traits (over a north-south gradient in Burkina Faso, as in other West African countries under a monsoon climate) and traits involved in yield components indicate that breeding programmes should be decentralised, with large-scale integration of local germplasm, which would ensure that the new breeding materials produced would be specifically adapted to local farming conditions.

The high morphological and genetic variability in sorghum varieties from Burkina Faso, in relation to the cropping system diversity, should be promoted in breeding programmes by developing different populations with a broad genetic base. This will preserve the diversity and help to develop new genetic recombinations to meet the needs of a changing range of adaptations and uses. Finally, the characterisation results highlighting farmers' preferences for anthocyanic varieties $(98.4 \%$ of the collected material) should be taken into account to facilitate the adoption of new cultivars. This concern could also be integrated in participative sorghum breeding initiatives that have now been underway for some years in Burkina Faso (vom Brocke et al. 2008).

Our results indicated that red kernel sorghum varieties for beer brewing are genetically and agromorphologically distinct entities that should be the focus of specific preservation initiatives. These varieties are a good example of the relationship between traditional uses, cropping systems and specific biological features that may be noted in several other traditional agricultural systems in sub-Saharan Africa. Sorghum conservation programmes should thus integrate social and cultural components, rather than being just based on abiotic environmental indicators.

Considering the limited contribution of the "village within zone" factor to the pattern of agromorphological diversity and the low genetic differentiation between villages, it appears that sorghum diversity within villages could be representative of diversity on a regional scale without any significant loss. Therefore, varieties collected in a thorough manner from only a limited number of villages could be representative of the cultivated sorghum diversity in Burkina Faso. Moreover, a network of local observatories (involving a limited number of villages selected in different geographical, climatic and ethnolinguistic zones) would be the best strategy for monitoring the evolution of sorghum genetic diversity in situ in Burkina Faso.
Acknowledgments This work was supported by Fonds Français pour l'Environnement Mondial (FFEM). We thank the various people who participated in the 2003 and 2004 sampling and specifically farmers who shared their varieties and knowledge. We thank Lauriane Rouan for the statistical treatment of the agromorphological data through the SAS software and Anthony Mc Gowan for editing the English of the final draft manuscript. We lastly thank André Charrier for his critical review of the manuscript..

\section{References}

Appa Rao S, Prasada RF, Mengesha MH, Gopal-Reddy V (1996) Morphological diversity in sorghum germplasm from India. Genet Resour Crop Evol 43:559-567

Barnaud A, Deu M, Garine E, McKey D, Joly HI (2007) Local genetic diversity of sorghum in a village in northern Cameroon: structure and dynamics of landraces. Theor Appl Genet 114:237-248

Barro-Kondombo C, vom Brocke K, Chantereau J, Sagnard F, Zongo JD (2008) Variabilité phénotypique des sorghos locaux de deux régions agricoles du Burkina Faso : la Boucle du Mouhoun et le Centre-Nord. Cah Agric 17:107-113

Benzecri JP (1984) L'analyse des données, 4th edn. Université Paris VI, Dunod

Bhattramakki D, Dong J, Chhabra AK, Hart GE (2000) An integrated SSR and RFLP linkage map of Sorghum bicolor (L.) Moench. Genome 43:988-1002

Brown MS, Hopkins MS, Mitchell SE, Senior ML, Wang TY, Duncan RR, Gonzalez-Candelas F, Kresovich S (1996) Multiple methods for the identification of polymorphic simple sequence repeats (SSRs) in sorghum [Sorghum bicolor (L.) Moench]. Theor Appl Genet 93:190-198

Brush SB (2000) The issue of in situ conservation of crop genetic resources. In: Brush SB (ed) Genes in the field: on-farm conservation of crop diversity. IDRC/IPGRI/Lewis Publishers, Boca Raton, pp 3-26

Casa MA, Mitchell SE, Hamblin HS, Sun H, Bowers JE, Paterson AH, Aquadro CF, Kresovich S (2005) Diversity and selection in sorghum: simultaneous analyses using simple sequence repeats. Theor Appl Genet 111:23-30

Christinck A, vom Brocke K, Kshirsagar KG, Weltzien E, Bramel-Cox PJ (2000) Participatory methods for collecting germplasm: experiences with farmers in Rajasthan, India. Genet Resour Crop Evol 121:1-9

Clerget B, Rattunde HFW, Dagnoko S, Chantereau J (2007) An easy way to assess photoperiod sensitivity in sorghum: relationships of the vegetative-phase duration and photoperiod sensitivity. J SAT Agric Res 3(1). http://www.icrisat.org/journal/Sorgum_ Millet_other_Cereals3.htm

Cui YX, Xu GW, Magill CW, Schertz KF, Hart GE (1995) RFLP based assay of Sorghum bicolor (L.) Moench genetic diversity. Theor Appl Genet 90:787-796

de Oliveira AC, Richter T, Bennetzen JL (1996) Regional and racial specificities in sorghum germplasm assessed with DNA markers. Genome 39:579-587

Deu M, Rattunde F, Chantereau J (2006) A global view of genetic diversity in cultivated sorghum using a core collection. Genome 49:168-180

Deu M, Sagnard F, Chantereau J, Calatayud C, Herault D, Mariac C, Pham J, Vigouroux Y, Kapran I, Traoré PS, Mamadou A, Gérard B, Ndjeunga J, Bezançon G (2008) Niger-wide assessment of in situ sorghum genetic diversity with microsatellites markers. Theor Appl Genet 116:903-913

Djé Y, Forciolo D, Ater M, Lefèbvre C, Vekemans X (1999) Assessing population genetic structure of sorghum landraces 
from North-Western Morocco using allozyme and microsatellite markers. Theor Appl Genet 99:157-163

Djé Y, Heuertz M, Lefèbvre C, Vekemans X (2000) Assessment of genetic diversity within and among germplasm accessions in cultivated sorghum using microsatellite markers. Theor Appl Genet 100:918-925

El Mousadik A, Petit RJ (1996) High level of genetic differentiation for allelic richness among populations of the argan tree [Argania spinosa (L.) Skeels] endemic to Morocco. Theor Appl Genet 92:832-839

Excoffier LGL, Schneider S (2005) Arlequin ver. 3.0: an integrated software package for population genetics data analysis. Evol Bioinform Online 1:47-50

Fahmy T (1999) XLSTAT-PRO. Paris, France

Folkertsma RF, Rattunde HFW, Chandra S, Soma Raju G, Hash CT (2005) The pattern of genetic diversity of guinea-race Sorghum bicolor (L.) Moench landraces as revealed with SSR markers. Theor Appl Genet 111:399-409

Folliard PC, Traoré PCS, Vaksmann M, Kouressy M (2004) Modeling of sorghum response to photoperiod: a threshold-hyperbolic approach. Field Crops Res 89:59-70

Ghebru B, Schmidt RJ, Bennetzen JL (2002) Genetic diversity of Eritrean sorghum landraces assessed with simple sequence repeat (SSR) markers. Theor Appl Genet 105:229-236

Goudet J (2001) FSTAT, a program to estimate and test gene diversities and fixation indices (version 2.9.3). http://www.unil. ch/popgen/softwares/fstat.htm

Grenier C, Bramel PJ, Dahlberg JA, El-Ahmadi A, Mahmoud M, Peterson GC, Rosenow DT, Ejeta G (2004) Sorghums of the Sudan: analysis of regional diversity and distribution. Genet Resour Crop Evol 51:489-500

Guinko S (1984). Végétation de la Haute-Volta. Phd Thesis, Université Bordeaux III, France

Harlan JR (1975) Crops and man. American Society of Agronomy, Madison

Harlan JR, de Wet JMJ (1972) A simplified classification of cultivated sorghum. Crop Sci 12:172-176

IBPGR/ICRISAT (1993) Descriptors for sorghum [Sorghum bicolor (L.) Moench]. International Board for Plant Genetic Ressources, Rome, Italy; International Crops Research Institute for the SemiArid Tropics, Patancheru, India

Kim J-S, Klein PE, Klein RR, Price HJ, Mullet JE, Stelly DM (2005) Chromosome identification and nomenclature of Sorghum bicolor. Genetics 169:955-965

Kong L, Dong J, Hart GE (2000) Characteristics, linkage-map positions, and allelic differentiation of Sorghum bicolor (L.) Moench DNA simple-sequence repeats (SSRs). Theor Appl Genet 101:438-448

Kouressy M, Bazile D, Vaksmann M, Soumaré M, Doucouré T, Sidibé A (2003) La dynamique des agroécosystémes : un facteur explicatif de l'érosion variétale du sorgho. In: Dugué $\mathrm{P}$, Jouve $\mathrm{P}$ (eds) Organisation spatiale et gestion des ressources et des territoires ruraux. Actes du colloque international, 25-27 février 2003, Montpellier, France, pp 42-50

Mantel N (1967) The detection of disease clustering and a generalized regression approach. Cancer Res 27:209-220

Menkir A, Goldsbrough P, Ejeta G (1997) RAPD based assessment of genetic diversity in cultivated races of sorghum. Crop Sci 37:564-569

Ministère de l'Agriculture de l'Hydraulique et des Ressources Halieutiques/Direction des Statistiques Agricoles (2006) Données sur les productions nationales. http://agristat.bf.tripod.com

Nei M (1987) Molecular evolutionary genetics. Columbia University Press, New York

Ollitrault P (1987) Evaluation génétique des sorghos cultivés (Sorghum bicolor L. Moench) par l'analyse conjointe des diversités enzymatique et morpho-physiologique. Relation avec les sorghos sauvages. PhD Thesis, Université Paris XI, France

Ollitrault P, Noyer JL, Chantereau J, Glaszmann JC (1997) Structure génétique et dynamique des variétés traditionnelles de sorgho au Burkina Faso. In: Begic A (ed) Gestion des Ressources Génétiques des Plantes en Afrique des Savanes. IER-BRG Solagral, Bamako, Mali, pp 231-240

Patterson HD, Williams ER (1976) A new class of resolvable incomplete block designs. Biometrika 63:83-92

Perrier X, Jacquemoud-Collet JP (2006) DARwin software. http://darwin.cirad.fr/darwin

Saitou N, Nei M (1987) The Neighbor-joining method: a new method for reconstructing phylogenetic trees. Mol Biol Evol 4:406-425

Schloss SJ, Mitchell SE, White GM, Kukatla R, Bowers JE, Paterson AH, Kresovich S (2002) Characterization of RFLP probe sequences for gene discovery and SSR development in Sorghum bicolor (L.) Moench. Theor Appl Genet 105:912-920

Snowden JD (1936) The cultivated races of Sorghum. Adlard, London, UK

Sokal RR, Michener CD (1958) A statistical method for evoluting systematic relationships. Univ Kansas Sci Bull 38:1409-1438

Stachel M, Lelly T, Grausgruber H, Vollmann J (2000) Application of microsatellites in wheat (Triticum aestivum L.) for studying genetic differentiation caused by selection for adaptation and use. Theor Appl Genet 100:242-248

Taramino G, Tarchini R, Ferrario S, Lee M, Pe ME (1997) Characterization and mapping of simple sequence repeats (SSRs) in Sorghum bicolor. Theor Appl Genet 95:66-72

Teshome A, Baum BR, Fahrig L, Torrance JK, Arnason TJ, Lambert JD (1997) Sorghum [Sorghum bicolor (L.) Moench] landrace variation and classification in north Shewa and South Welo, Ethiopia. Euphytica 97:255-263

Traoré SB, Reyniers F, Vaksmann M, Kone B, Sidibé A, Yoroté A, Yattara K, Kouressy M (2000) Adaptation à la sécheresse des écotypes locaux de sorghos du Mali. Sécheresse 11:227-237

Uptmoor R, Wenzel W, Friedt W, Donaldson G, Ayisi K, Ordon F (2003) Comparative analysis on the genetic relatedness of Sorghum bicolor accessions from Southern Africa by RAPD, AFLPs and SSRs. Theor Appl Genet 106:1316-1325

vom Brocke K, Trouche G, Zongo S, Bitie A, Oualbéogo A, BarroKondombo C, Weltzien E, Chantereau J (2008) Création et amélioration in situ de populations à base génétique large avec les agriculteurs au Burkina Faso. Cah Agric 17:146-153

Ward JH (1963) Hierarchical grouping to optimize an objective function. J Am Stat Assoc 58:236-244

Weir BS, Cockerham CC (1984) Estimating F-statistics for the analysis of population structure. Evolution 38:1358-1370

Wendorf F, Close AE, Schild R, Wasylikowa K, Housley RA, Harlan JR, Krolik H (1992) Saharan exploitation of plants 8000 years BP. Nature 359:721-724

Wilcoxon F (1945) Individual comparison by ranking methods. Biometrics 1:80-83

Yagoua ND (1994) Caractérisation du sorgho pluvial, (Sorghum bicolor (L.) Moench), de la zone soudanienne du Tchad. In actes de l'atelier de formation sur les variétés locales de sorgho du 10-14 octobre 1994. Samanko, Mali, pp 44-59

Zongo JD (1991) Ressources génétiques des sorghos (Sorghum bicolor L. Moench) du Burkina Faso: evaluation agromorphologique et génétique. $\mathrm{PhD}$ Thesis, Université d'Abidjan, Côte d'Ivoire

Zongo JD, Gouyon PH, Sarr A, Sandmeier M (2005) Genetic diversity and phylogenic relations among Sahelian sorghum accessions. Genet Resour Crop Evol 52:869-878 